\title{
Fucoidan, a major component of brown seaweed, prohibits the growth of human cancer cell lines in vitro
}

\author{
SUGURU FUKAHORI ${ }^{1-3}$, HIROHISA YANO $^{1,3}$, JUN AKIBA ${ }^{1,3}$, SACHIKO OGASAWARA $^{1,3}$, \\ SEIYA MOMOSAKI ${ }^{1,3}$, SAKIKO SANADA ${ }^{1,3}$, KEITARO KURATOMI ${ }^{1,3}$, YASUHIRO ISHIZAKI ${ }^{1,3}$, \\ FUKUKO MORIYA $^{1,3}$, MINORU YAGI ${ }^{2,3}$ and MASAMICHI KOJIRO ${ }^{1,3}$ \\ ${ }^{1}$ Departments of Pathology, and ${ }^{2}$ Pediatric Surgery, Kurume University School of Medicine; ${ }^{3}$ Research Center of Innovative
Cancer Therapy of the 21 st Century COE Program for Medical Science, Kurume University, Kurume 830-0011, Japan
}

Received March 7, 2008; Accepted April 30, 2008

\begin{abstract}
Fucoidan, the general term for sulfated polysaccharides, is reported to engage in various biological activities having anti-tumor, anti-coagulation and anti-viral effects. Though it has been investigated, the mechanism of its antitumor effects remains elusive. The current study examined the anti-tumor effects of fucoidan extracted from Okinawa mozuku on 15 human cancer cell lines (6 hepatocellular carcinomas, 1 cholangiocarcinoma, 1 gallbladder cancer, 2 ovarian cancers, 1 hepatoblastoma, 1 neuroblastoma and 3 renal cancers) using an MTT assay. Changes in apoptosis and the cell cycle were analyzed by flow cytometry. The results revealed that cell proliferation was suppressed in 13 cell lines in a time- and/or dose-dependent manner; this suppression was marked in the hepatocellular carcinoma, cholangiocarcinoma and gallbladder carcinoma cell lines. In contrast, proliferation of the neuroblastoma and 1 of the 2 ovarian carcinoma cell lines was not affected. The ratio of apoptotic cells significantly increased in 5 of the 6 hepatocellular carcinoma cell lines, and the ratio of $\mathrm{G}_{2} / \mathrm{M}$ cells increased in the 3 hepatocellular cell lines examined. These observations indicate that fucoidan is a potential anti-tumor agent for the treatment of bile duct cancers, such as hepatocellular carcinoma, cholangiocarcinoma and gall-bladder carcinoma.
\end{abstract}

\section{Introduction}

Malignant tumors are a major cause of death in humans and, though treatment methods for cancer have markedly progressed, curative regimens and protocols are still under investigation. At present, chemotherapy is regarded as the most effective treatment for solid tumors.

Correspondence to: Dr Suguru Fukahori, Department of Pathology and Pediatric Surgery, Kurume University School of Medicine, 67 Asahi-machi, Kurume, Fukuoka 830-0011, Japan

E-mail: s_fukahori@med.kurume-u.ac.jp

Key words: fucoidan, apoptosis, cell cycle, anti-tumor
Recent studies have shown that the natural substances extracted from green tea (1) and marine products, among others, have favorable preventive effects against cancers. 'Mozuku' (brown seaweed) is a marine plant which grows offshore around Okinawa Island. It has attracted the attention of scientists as well as the general public, and is considered a food which has various beneficial effects on the body. Fucoidan, the major component of 'mozuku', is the general term used for sulfated polysaccharides, which are also found in other seaweeds such as 'wakame', 'hijiki', 'mekabu'. Sulfated polysaccharides are reported to engage in various biological activities having anti-tumor effects (2-6), antithrombin activity $(7,8)$, anti-coagulant activity (9) and antiviral effects $(10,11)$. Their anti-tumor effects have been investigated using various methods, but the mechanism of their action has remained elusive.

In order to increase the understanding of these anti-tumor effects, this in vitro study was conducted using 15 cell lines from 5 types of human cancers (liver cancer, cholangiocarcinoma, ovarian cancer, hepatoblastoma and neuroblastoma) along with fucoidan extracted from 'Okinawa mozuku'.

\section{Materials and methods}

Preparation of culture medium with fucoidan. Fucoidan solution was kindly provided by FCC Horiuchi \& Co. (Kurume, Japan). The fucoidan was extracted from mozuku (Cladosiphon Okamuranus Tokida) collected from the shores of Okinawa Island in Japan, sold as a sea product (containing fucose $22.1 \mathrm{mg} / 100 \mathrm{mg}$ ) with government approval, and used as raw material for a health drink. The structure of the polysaccharide from $C$. okamuranus has been investigated previously $(12,13)$.

The basal medium for cell culture was Dulbecco's modified Eagle's medium (Nissui Seiyaku Co., Tokyo, Japan) supplemented with $5 \%$ fetal bovine serum (Whittaker Bioproducts Inc., Walkersville, MD), $100 \mathrm{units} / \mathrm{ml}$ penicillin, and $100 \mu \mathrm{g} / \mathrm{ml}$ streptomycin (Gibco, Chagrin Falls, OH). Fucoidan was diluted with this medium and prepared in 10 concentrations $(0.35,0.70,1.40,2.82,5.63,11.25,22.50,45,90$ and $180 \mu \mathrm{g} /$ $\mathrm{ml})$. The osmotic pressures and $\mathrm{pH}$ values of the cultures with or without fucoidan were within normal physiological range. 

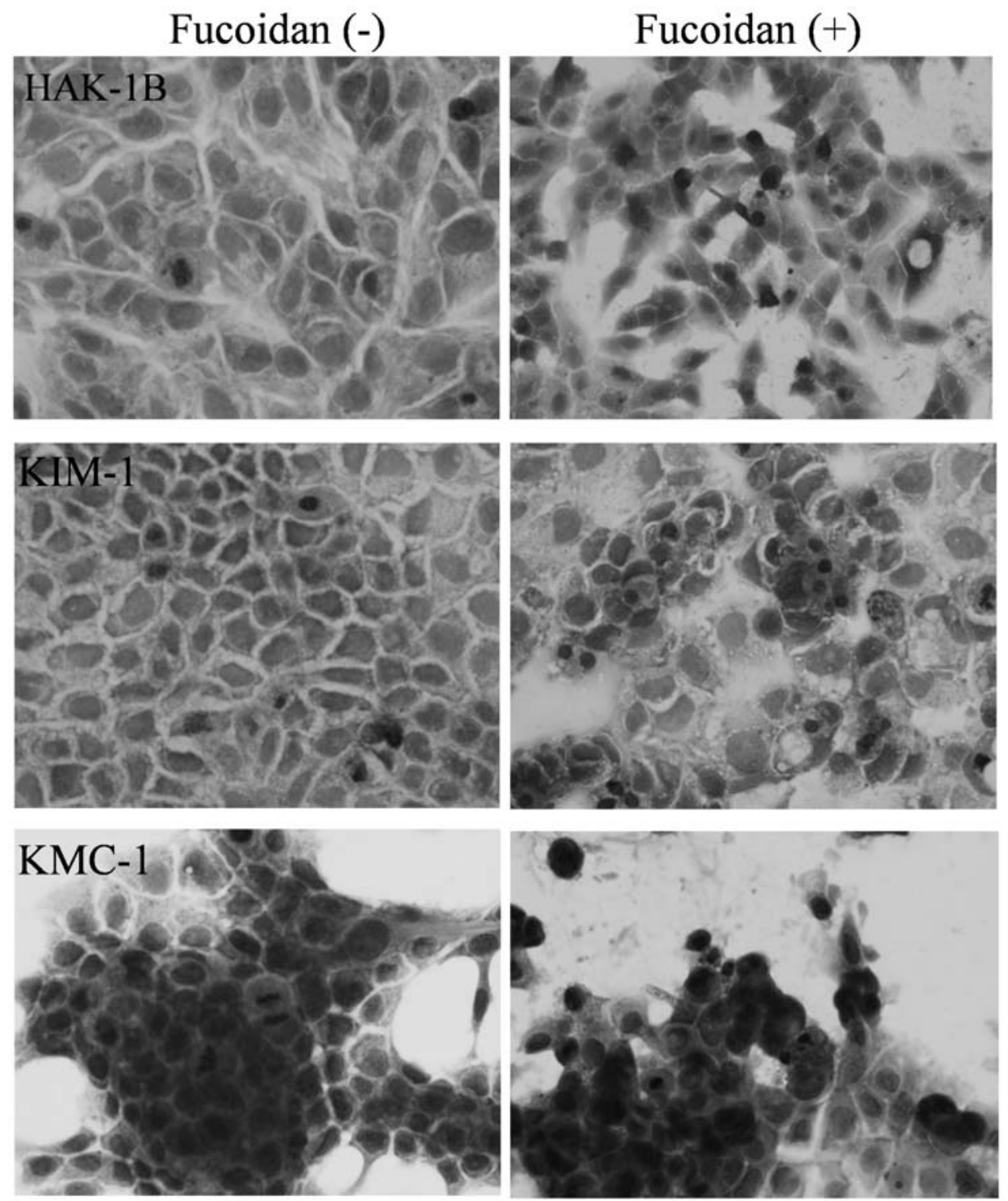

Figure 1. Photomicrograph of HAK-1B (A and B), KIM-1 (C and D) and KMC-1 (E and F) cells cultured for $72 \mathrm{~h}$ on a Lab-Tek Chamber slide. (A, C and E) No fucoidan in culture medium. Some mitotic figures were noted. (B, D and F) With $22.5 \mu \mathrm{g}$ of fucoidan in culture medium. Apoptotic cells were characterized by cytoplasmic shrinkage, chromatic condensation and nuclear fragmentation (H\&E staining, x200).

Cell lines and cell culture. Fifteen cell lines were used. These included 6 human hepatocellular carcinoma (HCC) cell lines [KIM-1 (12,14), KYN-1 (15), KYN-2 (16), KYN-3 (17), HAK-1A, HAK-1 (18)], one cholangiocarcinoma cell line (KMC-1) (19) and one gallbladder carcinoma cell line (KMG-C) which were originally established in our laboratory. Two human ovarian clear cell carcinoma cell lines (KOC-5C and KOC-7C) were established as described elsewhere $(20,21)$, as were 3 human renal cell carcinoma cell lines (KURU II, KURM and OSRC2) (22). The human neuroblastoma cell line (SK-N-SE) was a generous gift from Dr K. Ueda of the Department of Pediatrics and Child Health of Kurume University. The human hepatoblastoma cell line (HuH-6) was purchased from the Japan Health Sciences Foundation (Osaka, Japan).

Observation of morphological changes. For light microscopic observations, the cells were seeded on Lab-Tek Tissue Culture Chamber Slides (Nunc Inc., Roskilde, Denmark), cultured with or without fucoidan $(2.82,22.5$ or $90 \mu \mathrm{g} / \mathrm{ml})$ for $72 \mathrm{~h}$, fixed in Carnoy's solution for $10 \mathrm{~min}$, then stained with hematoxylin and eosin (H\&E) and observed under a microscope (Olympus BH-2, Olympus Optical, Tokyo, Japan).

Effect of fucoidan on the proliferation of each cell line. The effect of fucoidan on cell proliferation was investigated with colorimetric assays using MTT [3-(4,5-dimethylthiazol-2yl-yl)2,5-diphenyltetrazolium bromide] cell growth assay kits (Chemicon International Inc., Temecula, CA) as previously described (23). Briefly, cells were seeded on 96-well plates (Falcon, Becton Dickinson Labware, Tokyo, Japan) and cultured for $24 \mathrm{~h}$. The medium was then replaced with $100 \mu \mathrm{l}$ of fresh medium alone or containing the diluted fucoidan solution $(0.35,0.70,1.40,2.82,5.63,11.25,22.50,45,90$ or $180 \mu \mathrm{g} / \mathrm{ml})$. After $24,48,72$ or $96 \mathrm{~h}$, the number of viable cells was counted. Each experiment was repeated at least twice. The $50 \%$ inhibitory concentration $\left(\mathrm{IC}_{50}\right)$ was defined as the fucoidan concentration $(\mu \mathrm{g})$ that caused a $50 \%$ reduction 
A

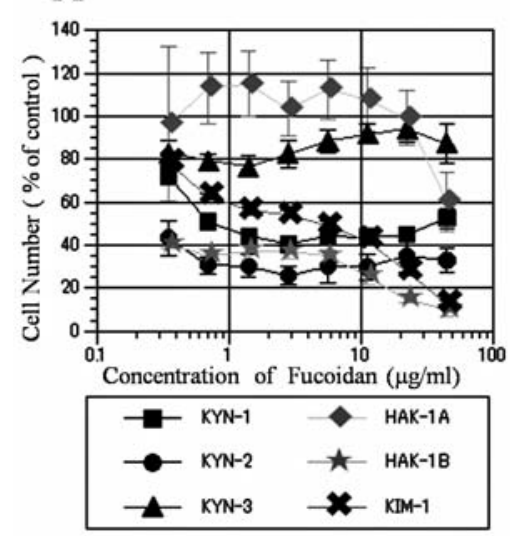

D

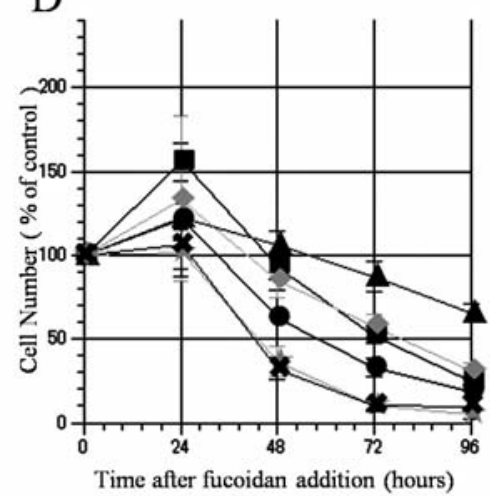

B

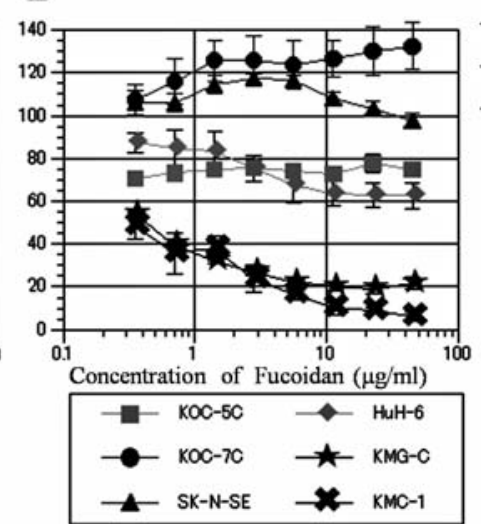

E

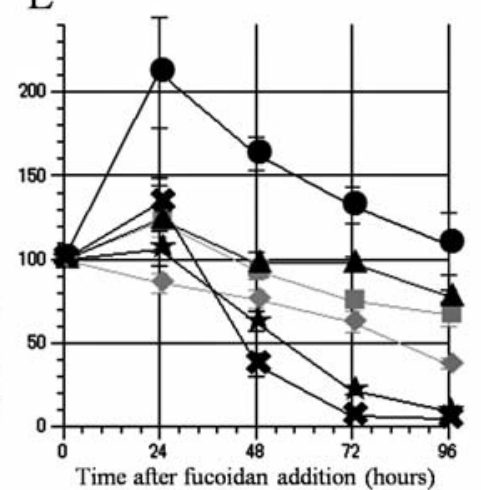

C
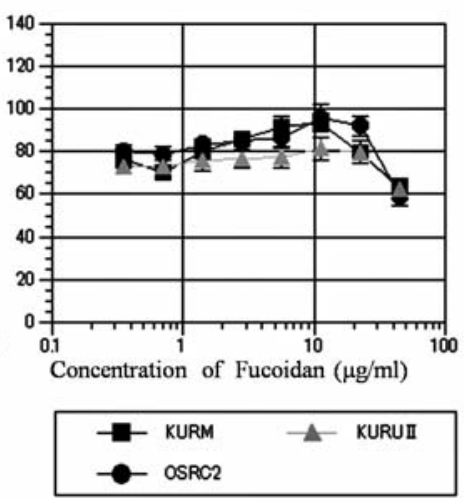

F

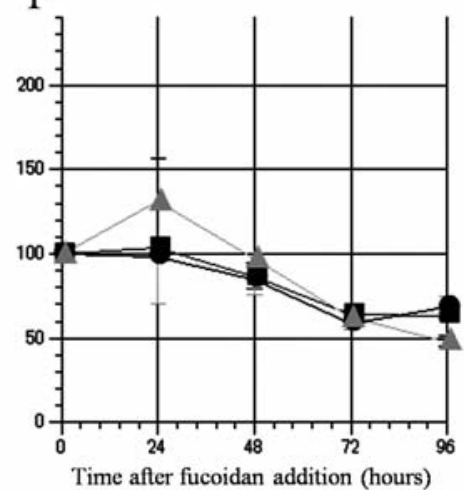

Figure 2. Antiproliferative effect of fucoidan (A-C) $72 \mathrm{~h}$ after $0.35,0.70,1.40,2.82,5.63,11.25,22.50$ or $45 \mu \mathrm{g}$ were added. Cell proliferation was suppressed in a dose-dependent manner in the 4 cell lines (KIM-1, HAK-1B, KMG-C, KMC-1), but not in the other 11 cell lines. The values represent the means \pm SE of the experiments. The experiment was repeated at least twice for each cell line. (D-F) Chronological changes in the relative viable cell number (\% of the control) after adding $22.5 \mu \mathrm{g}$ of fucoidan. A time-dependent growth inhibition was observed in 13 cell lines with the exception of KOC-7C, and growth was suppressed over time to varying degrees.

in cellular viability. The $\mathrm{IC}_{50}$ value was calculated and used as a parameter in the comparison of the relative cytotoxicity of each cell line.

Quantitative analysis of fucoidan-induced apoptosis. Six HCC cell lines were cultured with or without fucoidan (22.5 or $90 \mu \mathrm{g} / \mathrm{ml}$ ) for $72 \mathrm{~h}$ and then stained with Annexin V-EGFP (enhanced green fluorescent protein) using Apoptosis Detection Kits (Medical \& Biological Laboratories, Nagoya, Japan) according to the manufacturer's protocol. After staining, the cells were analyzed using a FACScan (Becton Dickinson Immunocytometry Systems, San Jose, CA), and the percentage of Annexin V-EGFP-positive cells was determined.

Cell cycle analysis. Three HCC cell lines (HAK-1A, KYN-2, KYN-3) were cultured with or without fucoidan $(22.5 \mu \mathrm{g} / \mathrm{ml})$ for 24,48 or $72 \mathrm{~h}$, labeled with $10 \mu \mathrm{mol} / \mathrm{l} \mathrm{BrdUrd}$ for $30 \mathrm{~min}$, fixed in $70 \%$ cold ethanol at $4^{\circ} \mathrm{C}$ overnight, and stained with anti-BrdUrd antibody and propidium iodide (Sigma Chemical Co., St. Louis, MO) using a previously described technique (23). The stained cells were analyzed by FACScan using the CellQuest software program (ver. 3.3, Becton Dickinson). The distribution of cells in the $G_{0} / G_{1}, S$, or $G_{2} / M$ phase of the cell cycle was calculated and shown as a percentage of each phase. Statistical analysis. All data were expressed as the means \pm SD. For data analysis, the Student's t-test was used. A P-value $<0.05$ was considered to be statistically significant.

\section{Results}

Effect of fucoidan on morphological changes. Cell morphology $72 \mathrm{~h}$ after the addition of fucoidan solution was observed using $\mathrm{H} \& \mathrm{E}$ staining. The cell density in culture decreased dosedependently (except for neuroblastoma) in order from HCC (KIM-1, HAK-1A, HAK-1B, KYN-1, KYN-2, KYN-3), cholangiocarcinoma (KMC-1), gallbladder carcinoma (KMG-C), renal cell carcinoma (KURU II, KURM, OSRC2), to ovarian cancer (KOC-5C, KOC-7C). The cell density of the neuroblastoma cell line (SK-N-SE) did not decrease at any concentration of fucoidan. As shown in Fig. 1, 3 HCC cell lines (HAK-1B, KIM-1 and KMC-1) presented dosedependent apoptotic changes such as nuclear condensation, cell shrinkage and nuclear fragmentation.

Effects of fucoidan on cell proliferation. MTT assay revealed chronological and dose-dependent suppression of the proliferation of 4 cell lines (HAK-1B, KIM-1, KMG-C and KMC-1), chronological suppression in 9 cell lines (KYN-1, KYN-2, KYN-3, HAK-1A, KOC-5C, HuH-6, KURM, OSRC2, KURU II), and no suppression in 2 cell lines (KOC-7C, SKN-SE) (Fig. 2).

The $\mathrm{IC}_{50}$ values at $72 \mathrm{~h}$ of culture ranged from 18.71 to $299.20 \mu \mathrm{g} / \mathrm{ml}$. Levels at $72 \mathrm{~h}$ could not be obtained for KMG-C, KMC-1, HAK-1B and KYN-2 because $>50 \%$ suppression occurred; however, at $48 \mathrm{~h}$ the $\mathrm{IC}_{50}$ was $13.33 \mu \mathrm{g}$ for 


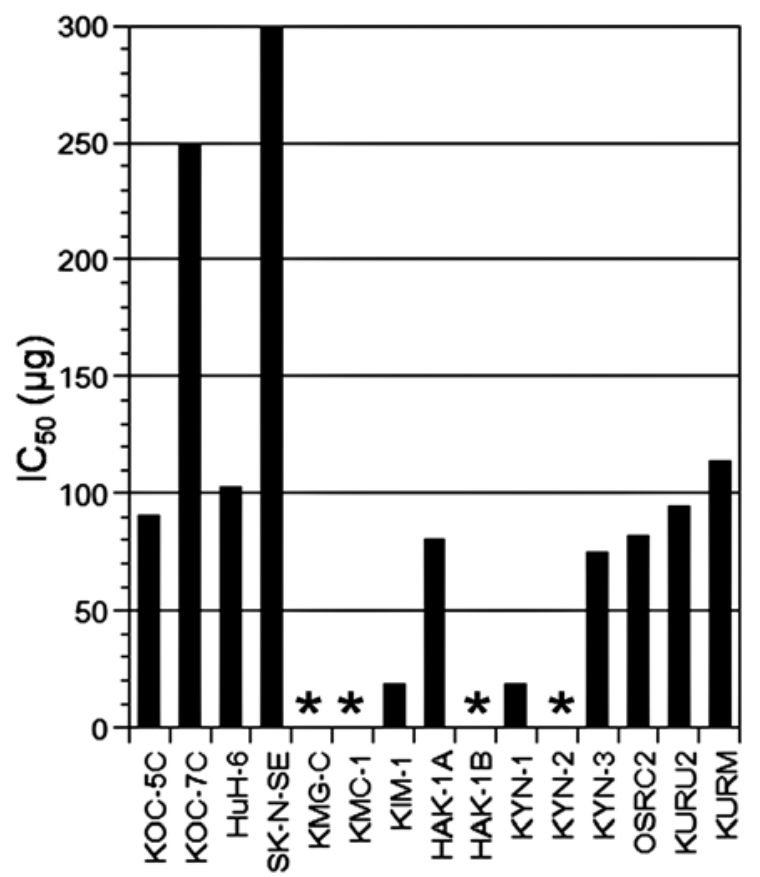

Figure 3. The $\mathrm{IC}_{50}$ of 15 cell lines treated with fucoidan for $72 \mathrm{~h}$. ${ }^{*} \mathrm{The}^{\mathrm{I}} \mathrm{I}_{50}$ values of KMG-C, KMC-1, HAK-1B and KYN-2 cell lines at $72 \mathrm{~h}$ could not be analyzed because the viable cell number was suppressed to $<50 \%$ for all concentration levels of fucoidan.

KMC-1, $50.64 \mu \mathrm{g}$ for HAK-1B, $52.32 \mu \mathrm{g}$ for $\mathrm{KYN}-2$ and $76.25 \mu \mathrm{g}$ for KMG-C. According to tumor type, the $\mathrm{IC}_{50}$ was lowest in HCC and cholangiocarcinoma (Fig. 3).

Effect of fucoidan on apoptosis. Apoptosis was examined at $72 \mathrm{~h}$ of culture in the 6 cell lines that presented pronounced growth suppression in the MTT assay. The number of apoptotic cells increased significantly in the $5 \mathrm{HCC}$ cell lines with the exception of KYN-1, indicating that fucoidan induced apoptosis (Fig. 4).

Effect of fucoidan on the cell cycle. Flow cytometry of the 3 HCC cell lines (HAK-1A, KYN-2, KYN-3) revealed an increased number of cells in the $\mathrm{G}_{2} / \mathrm{M}$ phase at $72 \mathrm{~h}$ after the addition of the fucoidan solution $(22.5 \mu \mathrm{g} / \mathrm{ml})$ to the culture (Table I).

\section{Discussion}

The current study examined the anti-tumor effect of Okinawa mozuku fucoidan on 15 human cancer cell lines. Chronological and/or dose-dependent suppression of cell proliferation was observed in 13 of the 15 lines $(87 \%)$. Previous studies have reported direct anti-tumor effects of fucoidan on HTLV-1infected T cell lines and primary ATL cells (24), lymphoma cells (25) and a bronchopulmonary carcinoma cell line (NSCLC-N6) (4). The various possible mechanisms of fucoidan have also been explored, such as its anti-tumor effect induced by anti-angiogenesis (5), growth suppression due to immunopotentiation (26), and the suppression of metastasis $(27,28)$, but only on one cell line. This current study investigated the effects had by fucoidan from the same source at the same time on multiple cell lines.

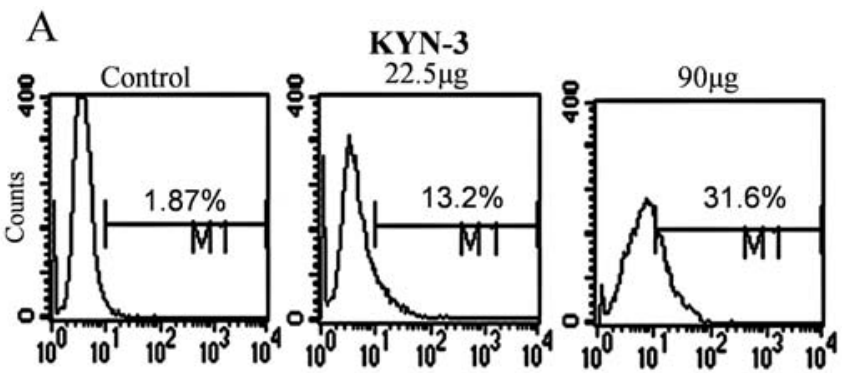

B

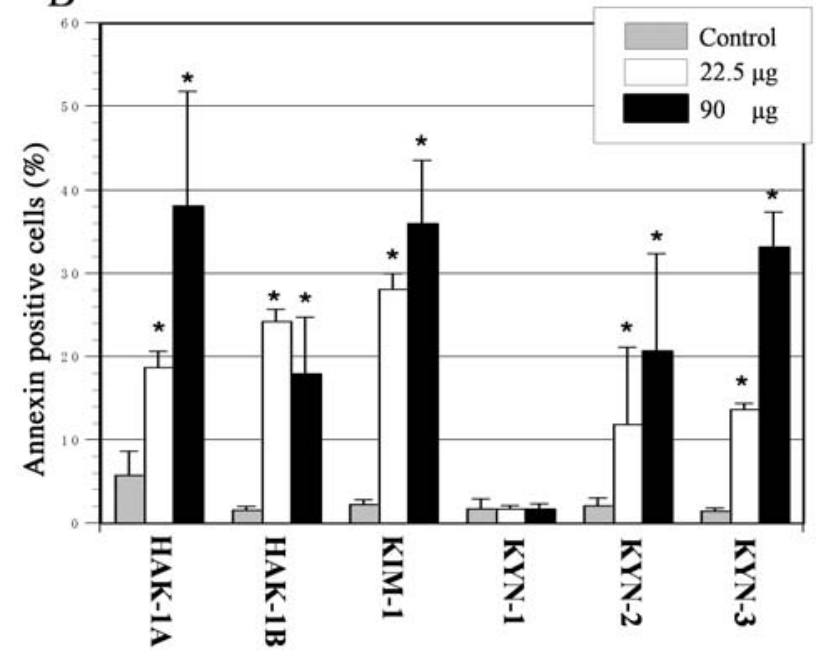

Figure 4. An analysis of apoptosis in 6 hepatocellular carcinoma cell lines treated with or without fucoidan for $72 \mathrm{~h}$. HAK-1A, HAK-1B, KIM-1, KYN-1, KYN-2 and KYN-3 cell lines were treated with or without fucoidan (22.5 or $90 \mu \mathrm{g}$ ) for $72 \mathrm{~h}$. The cells were harvested, labeled with Annexin-V-FITC and then analyzed by flow cytometry. (A) Percentage of apoptotic cells in the KYN-3 cell line. (B) Data represent the average $( \pm S E)$ percentage of apoptotic cells. ${ }^{*} \mathrm{P}<0.001$ vs. untreated cells.

The major components of fucoidan are L-fucose and sulfate content. Previous studies used fucoidan extracted from Fucus vesiculosus (25), Ascophyllum nodosum (4,7), Sargassum kjellmanianum (29), Sargassum thunbergii (26) or Cladosiphon okamuranus Tokida (24), in which the percentage of L-fucose ranged from 12.6 to $36.0 \%$, and the percentage of sulfate content from 8 to $25 \%$. Sulfate content was also reported to be a factor with growth suppression effects $(4,29)$. The fucoidan solution used in the current study contained these 2 substances within the above-mentioned ranges.

In this study, the suppression of cell proliferation was more apparent in the cell lines of HCC, cholangiocarcinoma and gallbladder carcinoma than in those of neuroblastoma, hepatoblastoma, ovarian carcinoma and renal carcinoma. The growth suppression effects also varied among the cell lines of the same tumor type. The $\mathrm{IC}_{50}$ values of the HAK-1B (HCC) and KMC-1 (cholangiocarcinoma) cell lines were additionally markedly lower in comparison to previously reported data $(4,25)$. These findings indicate that the anti-tumor effects of fucoidan vary according to tumor type and, along with previous findings, demonstrate the anti-tumor effects of fucoidan on colon cancer but not on mammary tumors (30). This indicates that the supression of cell proliferation does not occur in all cancer cell lines. The mechanism behind the more potent growth suppression observed in the HCC and cholangiocarcinoma cell lines should therefore be explored in future studies. 
Table I. Flow cytometric analysis of the effect of fucoidan $(22.5 \mu \mathrm{g} / \mathrm{ml})$ on the cell cycle of hepatocellular carcinoma cell lines at 24,48 and $72 \mathrm{~h}$ of culture.

\begin{tabular}{|c|c|c|c|c|c|c|c|}
\hline \multirow[b]{2}{*}{ Cell line } & \multirow[b]{2}{*}{ Cell cycle } & \multicolumn{2}{|c|}{$24 \mathrm{~h}$} & \multicolumn{2}{|c|}{$48 \mathrm{~h}$} & \multicolumn{2}{|c|}{$72 \mathrm{~h}$} \\
\hline & & Control & Fucoidan & Control & Fucoidan & Control & Fucoidan \\
\hline \multirow[t]{3}{*}{ HAK-1A } & $\mathrm{G}_{0} / \mathrm{G}_{1}$ & 30.7 & 24.3 & 38.4 & 22.8 & 42.9 & 20.5 \\
\hline & $\mathrm{S}$ & 48.8 & 37.6 & 36.9 & 46.3 & 38.1 & 44.1 \\
\hline & $\mathrm{G}_{2} / \mathrm{M}$ & 16.2 & 22.9 & 18.9 & 22.4 & 13.9 & 19.2 \\
\hline \multirow[t]{4}{*}{ KYN-2 } & $\mathrm{G}_{0} / \mathrm{G}_{1}$ & 26.1 & 28.8 & 31.9 & 32.2 & 34.0 & 44.4 \\
\hline & $\mathrm{S}$ & 57.7 & 31.2 & 46.8 & 37.7 & 32.1 & 21.1 \\
\hline & $\mathrm{G}_{2} / \mathrm{M}$ & 12.2 & 28.6 & 9.7 & 20.1 & 18.6 & 23.5 \\
\hline & $\mathrm{G}_{0} / \mathrm{G}_{1}$ & 32.0 & 35.2 & 42.1 & 37.8 & 46.0 & 49.4 \\
\hline \multirow[t]{2}{*}{ KYN-3 } & $\mathrm{S}$ & 53.6 & 27.0 & 41.4 & 34.8 & 35.7 & 29.5 \\
\hline & $\mathrm{G}_{2} / \mathrm{M}$ & 9.5 & 31.9 & 11.1 & 23.5 & 12.9 & 17.0 \\
\hline
\end{tabular}

Control, cells cultured without fucoidan. Fucoidan, cells cultured with fucoidan $(22.5 \mu \mathrm{g} / \mathrm{ml})$. Values represent the percentage of cells at each phase of the cell cycle.

Haneji et al (24) reported that apoptosis is induced by the activation of the caspase pathway, and Aisa et al (25) demonstrated anti-tumor effects accompanied by the activation of the caspase pathway and the down-regulation of the ERK pathway. In the current study, 5 of the $6 \mathrm{HCC}$ cell lines presented a significant dose-dependent increase in apoptosis. The activation of caspase- 3 and -9 in HAK-1B, which presented marked apoptosis, was therefore investigated. However, no clear activation was observed (data not shown), indicating that the anti-tumor effects of fucoidan on HCC cell lines could be associated with a different pathway.

With regard to cell cycle effect, Haneji et al (24) reported that fucoidan induced the accumulation of cells in the $\mathrm{G}_{1} / \mathrm{S}$ phase, and Riou et al (4) observed that anti-tumor effects were accompanied by a $G_{1}$ phase block. On the other hand, Aisa et al (25) reported no effect on the cell cycle. The current findings regarding the cell cycle demonstrate for the first time an increase in cells in the $\mathrm{G}_{2} / \mathrm{M}$ phase.

In the current study, fucoidan suppressed cell proliferation in a time- and dose-dependent manner at various degrees, and its effects were particularly pronounced in the HCC, cholangiocarcinoma and gallbladder carcinoma cell lines. The results indicate that the mechanisms of fucoidan action include the induction of apoptosis and the inhibition of the cell cycle.

At present, the clinical results of treatment for advanced HCC and cholangiocarcinoma are unsatisfactory. Fucoidan could be a potential anti-tumor remedy for specific cancers, such as HCC or cholangiocarcinoma. More detailed information on the anti-tumor effects of fucoidan should therefore be obtained in future animal studies.

\section{Acknowledgements}

We thank Ms. Akemi Fujiyoshi for her valuable assistance with our experiments.

\section{References}

1. Nakachi K, Matsuyama S, Miyake S, Suganuma M and Imai K: Preventive effects of drinking green tea on cancer and cardiovascular disease: epidemiological evidence for multiple targeting prevention. Biofactors 13: 49-54, 2000

2. Parish CR, Coombe DR, Jakobsen KB, Bennett FA and Underwood PA: Evidence that sulfated polysaccharides inhibit tumour metastasis by blocking tumour-cell-derived heparanases. Int J Cancer 40: 511-518, 1987.

3. Zhuang $\mathrm{C}$, Itoh $\mathrm{H}$, Mizuno $\mathrm{T}$ and Ito $\mathrm{H}$ : Antitumor active fucoidan from the brown seaweed, umitoranoo (Sargassum thunbergii). Biosci Biotechnol Biochem 59: 563-567, 1995.

4. Riou D, Colliec-Jouault S, Pinczon du Sel D, et al: Antitumor and antiproliferative effects of a fucan extracted from ascophyllum nodosum against a non-small-cell broncho-pulmonary carcinoma line. Anticancer Res 16: 1213-1218, 1996.

5. Koyanagi S, Tanigawa N, Nakagawa H, Soeda S and Shimeno H: Oversulfation of fucoidan enhances its anti-angiogenic and antitumor activities. Biochem Pharmacol 65: 173-179, 2003.

6. Maruyama $\mathrm{H}$, Tamauchi $\mathrm{H}$, Hashimoto $\mathrm{M}$ and Nakano $\mathrm{T}$ : Antitumor activity and immune response of Mekabu fucoidan extracted from Sporophyll of Undaria pinnatifida. In Vivo 17: 245-249, 2003.

7. Colliec S, Fischer AM, Tapon-Bretaudiere J, Boisson C, Durand $\mathrm{P}$ and Jozefonvicz J: Anticoagulant properties of a fucoidan fraction. Thromb Res 64: 143-154, 1991.

8. Trento F, Cattaneo F, Pescador R, Porta R and Ferro L: Antithrombin activity of an algal polysaccharide. Thromb Res 102: 457-465, 2001.

9. Durig J, Bruhn T, Zurborn KH, Gutensohn K, Bruhn HD, and Beress L: Anticoagulant fucoidan fractions from Fucus vesiculosus induce platelet activation in vitro. Thromb Res 85: 479-491, 1997.

10. Baba M, Schols D, Pauwels R, Nakashima H and De Clercq E: Sulfated polysaccharides as potent inhibitors of HIV-induced syncytium formation: a new strategy towards AIDS chemotherapy. J Acquir Immune Defic Syndr 3: 493-499, 1990.

11. McClure MO, Moore JP, Blanc DF, et al: Investigations into the mechanism by which sulfated polysaccharides inhibit HIV infection in vitro. AIDS Res Hum Retroviruses 8: 19-26, 1992.

12. Nagaoka M, Shibata H, Kimura-Takagi I, et al: Structural study of fucoidan from Cladosiphon okamuranus tokida. Glycoconj J 16: 19-26, 1999.

13. Sakai T, Ishizuka K, Shimanaka K, Ikai K and Kato I: Structures of oligosaccharides derived from Cladosiphon okamuranus fucoidan by digestion with marine bacterial enzymes. Mar Biotechnol 5: 536-544, 2003. 
14. Murakami T: Establishment and characterization of a new human hepatocellular carcinoma cell line (KIM-1). Acta Hepatol Jpn 25: 532-539, 1988.

15. Yano H, Kojiro M and Nakashima T: A new human hepatocellular carcinoma cell line $(\mathrm{KYN}-1)$ with a transformation to adenocarcinoma. In Vitro Cell Dev Biol 22: 637-646, 1986.

16. Yano H, Maruiwa M, Murakami T, et al: A new human pleomorphic hepatocellular carcinoma cell line, KYN-2. Acta Pathol Jpn 38: 953-966, 1988.

17. Murakami T, Maruiwa M, Fukuda K, Kojiro M, Tanaka M and Tanikawa K: Characterization of a new human hepatoma cell line $(\mathrm{KYN}-3)$ derived from the ascites of the hepatoma patient [abstract]. Jpn J Cancer Res Proceedings of the Japanese Cancer Association 192, 1988.

18. Yano H, Iemura A, Fukuda K, Mizoguchi A, Haramaki M and Kojiro M: Establishment of two distinct human hepatocellular carcinoma cell lines from a single nodule showing clonal dedifferentiation of cancer cells. Hepatology 18: 320-327, 1993.

19. Iemura A, Maruiwa M, Yano H and Kojiro M: A new human cholangiocellular carcinoma cell line (KMC-1). J Hepatol 15: 288-298, 1992.

20. Tomioka Y: Establishment and characterization of three human ovarian clear cell carcinoma cell line. J Kurume Med Assoc 61: 323-333, 1998.

21. Takemoto Y, Yano H, Momosaki S, et al: Antiproliferative effects of interferon-alphaCon1 on ovarian clear cell adenocarcinoma in vitro and in vivo. Clin Cancer Res 10: 7418-7426, 2004.

22. Inoue M, Yano H and Kojiro M: Expression of Fas and antimediated apoptosis in human renal cell carcinoma. Int J Oncol 9: 49-56, 1996.
23. Yano H, Iemura A, Haramaki M, et al: Interferon alfa receptor expression and growth inhibition by interferon alfa in human liver cancer cell lines. Hepatology 29: 1708-1717, 1999.

24. Haneji K, Matsuda T, Tomita M, et al: Fucoidan extracted from Cladosiphon okamuranus Tokida induces apoptosis of human $\mathrm{T}$ cell leukemia virus type 1 -infected T-cell lines and primary adult T-cell leukemia cells. Nutr Cancer 52: 189-201, 2005.

25. Aisa Y, Miyakawa Y, Nakazato T, et al: Fucoidan induces apoptosis of human HS-sultan cells accompanied by activation of caspase-3 and down-regulation of ERK pathways. Am J Hematol 78: 7-14, 2005.

26. Itoh $\mathrm{H}$, Noda $\mathrm{H}$, Amano $\mathrm{H}$ and Ito $\mathrm{H}$ : Immunological analysis of inhibition of lung metastases by fucoidan (GIV-A) prepared from brown seaweed Sargassum thunbergii. Anticancer Res 15: 1937-1947, 1995.

27. Coombe DR, Parish CR, Ramshaw IA and Snowden JM: Analysis of the inhibition of tumour metastasis by sulphated polysaccharides. Int J Cancer 39: 82-88, 1987.

28. Liu JM, Haroun-Bouhedja F and Boisson-Vidal C: Analysis of the in vitro inhibition of mammary adenocarcinoma cell adhesion by sulphated polysaccharides. Anticancer Res 20: 3265-3271, 2000.

29. Yamamoto I, Takahashi M, Suzuki T, Seino H and Mori H: Antitumor effect of seaweeds. IV. Enhancement of antitumor activity by sulfation of a crude fucoidan fraction from Sargassum kjellmanianum. Jpn J Exp Med 54: 143-151, 1984.

30. Ellouali M, Boisson-Vidal C, Durand P and Jozefonvicz J: Antitumor activity of low molecular weight fucans extracted from brown seaweed Ascophyllum nodosum. Anticancer Res 13: 2011-2019, 1993. 